\title{
Health quality and germination of Butia capitata seeds treated with bactericide and fungicide
}

\author{
Vander Rocha Lacerda ${ }^{1}$; Diemesson San Tiago Mendes ${ }^{1}$; Fernando da Silva Rocha ${ }^{1 *}$; Maria de Fátima Gonçalves \\ Fernandes ${ }^{1}$; Paulo Sergio Nascimento Lopes ${ }^{1}$; Nody Civili²; Hugo Cesar Rodrigues Moreira Catão ${ }^{3}$
}

${ }^{1}$ Universidade Federal de Minas Gerais, Av. Universitária 1000, Bairro Universitário, CEP 39404-547, Montes Claros, MG, Brazil. ${ }^{2}$ Laval University, G1V 0A7, Québec City, Quebec, Canada. ${ }^{3}$ Faculdades Integradas de Ourinhos, CEP 19909-100, Ourinhos, São Paulo, Brazil.

${ }^{*}$ Corresponding author: Fernando da Silva Rocha (rochafsplant@yahoo.com.br).

Data de chegada: 22/09/2015. Aceito para publicação em: 30/03/2016.

$10.1590 / 0100-5405 / 2128$

\begin{abstract}
Lacerda, V. R.; Mendes, D.S.T.; Rocha, F.S.; Fernandes, M.F.G.; Lopes, P.S.N.; Civil, N.; Catão, H.C.R.M. Health quality and germination of Butia capitata seeds treated with bactericide and fungicide. Summa Phytopathologica, v.42, n.4, p.303-307, 2016.

Propagation of "coquinho-azedo" (Butia capitata) is limited due to dormancy and high incidence of fungi in its seeds. The aim of this study was to evaluate the effect of treating "coquinho-azedo" seeds with different concentrations of bactericide and/or fungicide on the incidence of fungi and on the germination of seeds. Thus, B. capitata seeds were immersed in four doses of the bactericide kasugamycin $(0,1.5,3.0$ and $4.5 \mathrm{~mL} / \mathrm{L})$ and/or in four concentrations of the fungicide carbendazim+ thiram $(0,2.92,5.84$ e $8.75 \mathrm{~mL} /$ $\mathrm{Kg}$ ), totaling 16 treatments. After the treatments, the operculum was removed from the seeds, which were placed on trays containing autoclaved sand, covered with transparent plastic film and kept in the nursery. In the germination test, treatments were distributed in randomized block design, factorial arrangement

of $4 \times 4$ (bactericidal doses $x$ fungicide doses), with four replicates of 50 seeds per plot. For the test of seed health quality, the Blotter test was employed in completely randomized design, using 20 replicates and 10 seeds. Health quality and germination were evaluated at 15 and 40 days after the treatment of seeds, respectively. There was no interaction between the bactericide and the fungicide on germination and control of fungi associated with seeds. However, there was an effect of fungicide concentrations on the evaluated parameters. We observed a negative correlation between the concentrations of the fungicide carbendazim + thiram and fungal incidence, and a positive correlation between the fungicide concentrations and seed germination. Therefore, fungicide treatment reduces the fungal incidence and provides better germination of B. capitata seeds.
\end{abstract}

Keywords: Carbendazim, thiram, “coquinho-azedo", fungus, incidence.

\section{RESUMO}

Lacerda, V. R.; Mendes, D.S.T.; Rocha, F.S.; Fernandes, M.F.G.; Lopes, P.S.N.; Civil, N.; Catão, H.C.R.M. Qualidade sanitária e germinação de sementes de Butia capitata tratadas com bactericida e fungicida. Summa Phytopathologica, v.42, n.4, p.303-307, 2016.

A propagação do coquinho-azedo (Butia capitata) é limitada devido a dormência e a alta incidência de fungos em suas sementes. O objetivo deste trabalho foi avaliar o efeito do tratamento de sementes de coquinho-azedo com diferentes concentrações de bactericida e/ou fungicida na incidência de fungos e na germinação das sementes. Para isto, sementes de coquinho-azedo foram imersas em quatro doses do bactericida kasugamicina $(0,1.5,3.0$ e 4.5 $\mathrm{mL} / \mathrm{L}) \mathrm{e} / \mathrm{ou}$ em quatro concentrações do fungicida carbendazim + thiram $(0$, 2.92, 5.84 e $8.75 \mathrm{~mL} / \mathrm{Kg}$ ), totalizando 16 tratamentos. Após o tratamento, retirou-se o opérculo das sementes, as quais foram colocadas em bandejas contendo areia autoclavada, revestidas com filme plástico transparente, e mantidas em viveiro. No teste de germinação, os tratamentos foram distribuídos em delineamento de blocos casualizados em esquema fatorial 4 x 4 (doses do bactericida e doses do fungicida), com 4 repetições de 50 sementes por parcela. Para o teste de sanidade foi empregado o método do "Blotter test" em delineamento inteiramente casualizado utilizando 20 repetições com 10 sementes. A qualidade sanitária e a germinação foram avaliadas 15 e 40 dias após o tratamento das sementes, respectivamente. Não houve interação entre o bactericida e o fungicida sobre a germinação e o controle dos fungos associados às sementes. Porém, houve efeito das concentrações de fungicida sobre os parâmetros avaliados. Observou-se correlação negativa entre as concentrações do fungicida carbendazim + thiram e a incidência fúngica e correlação positiva entre as concentrações do fungicida e a germinação das sementes. Portanto, o tratamento fungicida reduz a incidência fúngica e propicia melhor germinação das sementes do coquinho-azedo.

Palavras-chave: Carbendazim, thiram, coquinho-azedo, fungo, incidência.

"Coquinho-azedo" (Butia capitata Mart. Becc.) is a palm tree native to the Cerrado biome and is especially found in the states of Bahia, Goiás and Minas Gerais in Brazil (1). Its fruits are commonly used in regional cuisine for fresh consumption and in the preparation of juices, ice cream, sweets and popsicles (17). The fruits are only exploited through intense extraction and in a predatory manner due to their high demand on the market (16) and play an important socio-economic role in regional communities where they naturally occur.

The dormancy phenomenon in B. capitata makes its germination low, slow and uneven (14). This phenomenon limits the production of seedlings for commercial crops, causing an unsustainable exploitation of this resource. The operculum of the endosperm is the main structure that limits the embryo emergence (22); thus, it is classified as physical dormancy, according to the classification system proposed by Baskin and Baskin (2). Therefore, an efficient technique to overcome the dormancy of B. capitata is to remove this structure (7). However, the operculum removal procedure greatly increases the risk of seed contamination by several fungi since, in addition to exposing the 
embryo, it causes injury to the operculum insertion point in the seed.

Some pathogenic fungi require the activities of the enzymes polygalacturonase and pectate lyase for cell wall degradation in the process of penetration and colonization of plant tissues. Studies about the health quality of $B$. capitata seeds have identified several fungal species such as Aspergillus flavus, A. niger, Penicillium spp. and Fusarium spp. (13). These fungi are producers of enzymes that cause seed deterioration $(11,28)$ and may directly reduce the germination potential and the vigor of seeds, consequently limiting the production of seedlings. Other enzymes produced by Aspergillus and Penicillium involved in the degradation of plant cell wall polysaccharides and the regulation of gene expression of these enzymes were revised (28). The procedure to minimize this contamination has been carried out under laminar flow chamber conditions and by using completely sterilized equipment (7). However, this method is difficult to be used in a rural environment and in poorly technified nurseries of seedling production.

Seed treatment with fungicide aiming to reduce contamination by fungi is an alternative to ensure the initial stand of plants in the cultivated area (1). Some systemic fungicides used for seed treatment would propitiate good results due to their protective and curative action on the plant tissue. Moreover, some products used in the treatment of embryos and seed disinfection usually affect the germination and the development of seedlings, since various fungicides produce phytotoxic effects at some dosages. Thus, determination of the concentrations of substances used in the control of microbial contamination is important for the establishment of protocols (26).

Considering the lack of studies involving chemical control in $B$. capitata seeds, the aim of this study was to evaluate the incidence of fungi in B. capitata seeds treated with different bactericidal doses (kasugamycin) and fungicide mixture (carbendazim + thiram), as well as their effect on seed germination.

\section{MATERIAL AND METHODS}

Fruits of B. capitata were collected in the municipality of Mirabela, state of Minas Gerais, in Brazil, from a natural population of plants. They were then taken to the Plant Propagation Laboratory at Federal University of Minas Gerais and stored during 4 months at room temperature. To remove the mesocarp (pulp) of these fruits, a low speed industrial blender was used. After pulping, the pyrenes (seed and endocarp) were dried in the shade for five days and stored in paper bags at room temperature for 30 days. Thereafter, with the aid of a lathe manual bench, the endocarp was removed to obtain the seeds. The humidity test of seeds was done by adopting the dry incubator method at $105^{\circ} \mathrm{C}$ for 24 hours (4), a sample of 5 replicates with 10 seeds.

Treatments with the fungicide and the bactericide were performed by immersing the seeds for 1 and 10 minutes, respectively. The experiment was conducted in $4 \times 4$ factorial arrangements, with four doses of the bactericide kasugamycin of $0,1.5,3.0$ and $4.5 \mathrm{~mL} / \mathrm{L}$ and/ or four doses of the fungicide carbendazim + thiram of $0,2.92,5.84$ and $8.75 \mathrm{~mL} / \mathrm{kg}$ of seeds, totaling 16 treatments. First, the seeds were immersed in the bactericide, and then in the fungicide. After treatment, the seeds were subjected to the operculum removal process according to the methodology proposed by Fior et al. (7). Then, for the germination test, the seeds were placed on trays containing sterilized and autoclaved sand and added of distilled water at $70 \%$ of its holding capacity. These trays were covered with transparent plastic film (PVC), forming thus a moist chamber around the seeds. The trays were kept in a greenhouse with $50 \%$ shade cloth. The temperature was daily monitored during the experiment. Each treatment consisted of four replicates of 50 seeds per plot in a randomized block design. After 40 days, the effects of treatment with bactericide and/or fungicide on the percentage of germination (emergence of the embryo) and the elongation of embryos were evaluated according the method proposed by Dias et al. (5), which considered germinated embryos $\geq 2 \mathrm{~mm}$ long.

Verification of the heath quality of $B$. capitata seeds was performed based on the Blotter test, according to Machado (12), with modifications. The seeds were treated with the fungicide and the bactericide as described above and incubated for 15 days under a photoperiod of 12 hours light and temperature of $25 \pm 2{ }^{\circ} \mathrm{C}$. The experimental design was randomized, using 20 replicates with 10 seeds. Quantitative and qualitative assessments of the fungi were obtained by individually examining the seeds under a stereoscopic microscope. The fungi present in the seeds were identified by using the identification key described by Klich and Pitt (10). In some cases, identification was confirmed by visualization of morphological structures of fungi under an optical microscope.

The normality of the data was analyzed according to Saphiro-Wilk test. As the data were not normally distributed, generalized linear models (GLM) were created. The quasibinomial error distribution test was used to analyze the relationship between the incidence of the three most abundant fungi (Curvularia sp., Aspergillus sp. and Penicillium sp.) and the different doses of bactericide and fungicide, as well as their interactions with the explanatory variables. The same error distribution was used for analysis of the final percentage of germinated seeds, non-germinated and elongated embryos according to the different doses of kasugamycin and carbendazim + thiram, and their interactions. Then, the analysis contrast with the CAR package was performed to compare means. We also tested the correlations of the effects of fungi, the percentage of germinated seeds, non-germinated and elongated embryos at different doses of bactericide and fungicide, using the Spearman correlation. All analyses were performed by using the statistical software $\mathrm{R}$. The p-value lower than 0.05 was considered significant.

\section{RESULTS AND DISCUSSION}

There was no significant interaction between the bactericide kasugamycin and the fungicide carbendazim + thiram on seed germination and fungal control. There was not any effect of the bactericide application on fungal incidence or seed germination. By analyzing the GLM, we observed a significant effect $(\mathrm{P}<0.05)$ of fungicide doses on all evaluated parameters. By analyzing the humidity test, the water content of the seeds used in the experiment was $8 \%$. Seed storage with high levels of water remains the major preservation method for recalcitrant seeds; however, it provides favorable conditions for the development of microorganisms (18).

The fungi showing the highest incidence on $B$. capitata seeds were Curvularia sp. (70.63\%), Penicillium spp. (13.76\%) and Aspergillus spp. $(6.89 \%)$ in the treatments without thiram + carbendazim (Table 1). Other fungi detected in the seeds were Bipolaris spp., Phomopis sp. and Drechslera sp. with incidence of less than $2.5 \%$. In B. capitata seeds with and without endocarp, occurrence of Aspergillus flavus, $A$. niger, Cladosporium sp., Epicoccum sp., Fusarium sp., Mucor sp., Penicillium sp. and Trichoderma sp. has been reported (13). Among the fungi reported in the literature to be detected in B. capitata seeds, some species of Fusarium and Aspergillus and Penicillium genera are associated with damping off of seedlings and deterioration of seeds. 
Table 1. Incidence of fungi detected on Butia capitata seeds treated with different doses of the fungicide carbendazim + thiram.

\begin{tabular}{cccc}
\hline \multirow{2}{*}{ Doses $(\mathbf{m L} / \mathbf{K g})$} & \multicolumn{3}{c}{ Incidence (\%) } \\
\cline { 2 - 4 } & Curvularia sp. & Penicillium spp. & Aspergillus spp. \\
\hline 0 & $70.63 \pm 4.13 \mathrm{a}$ & $13.76 \pm 3.63 \mathrm{a}$ & $6.89 \pm 2.53 \mathrm{a}$ \\
5.92 & $15.63 \pm 3.15 \mathrm{~b}$ & $16.26 \pm 5.15 \mathrm{a}$ & $2.52 \pm 1.70 \mathrm{~b}$ \\
8.75 & $1.27 \pm 0.85 \mathrm{c}$ & $1.27 \pm 0.85 \mathrm{~b}$ & $0.25 \pm 0.00 \mathrm{c}$ \\
\end{tabular}

Means followed by the same letter in the column do not differ according to contrast analysis at $5 \%$ probability. Data represent the average percentage values of 20 replicates. Values represent Mean \pm standard error.

Table 2. Average percentage values of germinated seeds, non-germinated seeds and elongated embryos of Butia capitata after seed treatment with the fungicide carbendazim + thiram at different doses.

\begin{tabular}{cccc}
\hline Doses (mL/Kg) & Seed germination (\%) & Non-germinated seeds (\%) & Elongated embryos (\%) \\
\cline { 2 - 4 } 0 & $10.00 \pm 2.58 \mathrm{c}$ & $83.13 \pm 3.33 \mathrm{a}$ & $6.26 \pm 2.56 \mathrm{~b}$ \\
2.92 & $39.38 \pm 3.59 \mathrm{~b}$ & $40.63 \pm 4.32 \mathrm{~b}$ & $20.62 \pm 2.49 \mathrm{a}$ \\
5.84 & $56.88 \pm 1.98 \mathrm{a}$ & $27.50 \pm 3.22 \mathrm{c}$ & $15.63 \pm 2.03 \mathrm{a}$ \\
8.75 & $62.50 \pm 1.44 \mathrm{a}$ & $23.75 \pm 2.87 \mathrm{c}$ & $18.75 \pm 3.01 \mathrm{a}$ \\
\hline
\end{tabular}

Means followed by the same letter in the column do not differ according to contrast analysis at $5 \%$ probability. Data represent the average percentage values of 4 replicates. Values represent Mean \pm standard error.

Contamination of $B$. capitata seeds occurs in the field, especially when the fruit falls to the ground, and during the fruit storage period. The fungi need enzymes such as cellulases, pectinases, amylases, lipases, proteases and nucleases to break the cell wall and promote the deterioration of seeds. In this study, a higher incidence of Curvularia sp. in B. capitata seeds was observed, as well as lower incidence of Penicillium spp. and Aspergillus spp. (Table 1). The genus Curvularia is considered of weak pathogens but is common in several seeds of plants of economic importance (24). However, considerable fungal infestations can compromise seed germination and vigor (23). Furthermore, Curvularia pallecens, detected in the seeds of various cereals, produces a large quantity of amylase and its virulence is associated with greater production of this enzyme (9). Masumi et al. (15) demonstrated the production of the enzyme amylase by thirty-three fungi endophytic from Thymus sp. but the greatest enzyme activity was produced by Curvularia akaii.

The fungi of the genera Penicillium and Aspergillus found at low incidence on $B$. capitata seeds are known to produce toxins and enzymes associated with the deterioration process. Fawole et al. (6) reported the production of pectinases and cellulases by Aspergillus flavus and Penicillium sp. and attributed the reduced germination of cowpea seeds and the virulence of these fungi to enzymatic activity. Rocha et al. (23) studied the physiological quality of soybean seeds at three inoculum levels and found $80 \%$ reduction in germination and seedling vigor and total tissue deterioration in seeds with incidence of up to or above $50 \%$ for A. ochraceus. In this study, the percentage of germinated seeds and elongated embryos treated with fungicide, compared to control, showed that the incidence of Curvularia sp., Penicillium spp. and Aspergillus spp. reduces the physiological quality of $B$. capitata seed, which may be due to their enzyme potential to deteriorate the cell wall (Tables 1 and 2).

Seed treatment with the studied fungicide doses $(2.92,5.84$ and $8.75 \mathrm{~mL} / \mathrm{kg}$ ) reduced the occurrence of fungi on B. capitata seeds (Table 1 and Figure 1). At higher doses, germination percentage with fungicide was also higher, compared to control (Table 2 and Figure 2). Seed treatment with fungicide addition to reduce the incidence of fungi also promotes better germination rate and emergence of plants $(8,19)$. Several studies have demonstrated fungal control on the seed

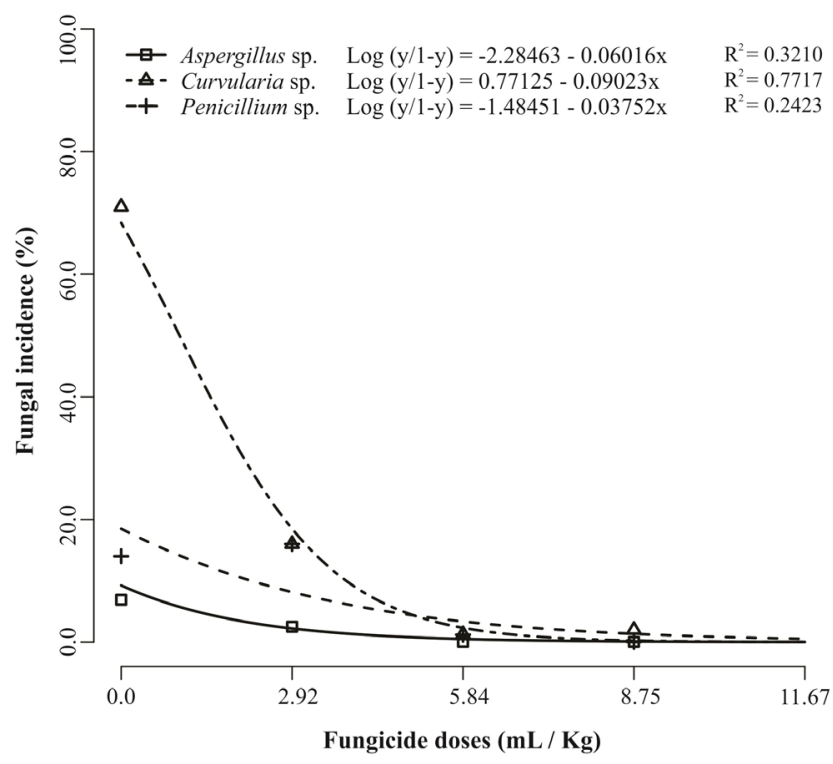

Figure 1. Incidence of Curvularia sp., Penicillium sp. and Aspergillus sp. associated with Butia capitata seeds treated with different doses of the fungicide carbendazim + thiram at 15 days after treatment.

by the fungicide carbendazim + thiram in several plant species (8). Tavares (27) observed that processing soybean seeds with the fungicide carbendazim + thiram at a dose of $2 \mathrm{~mL} / \mathrm{kg}$ of seed reduced the incidence of Penicillium spp., Rhizopus spp., Aspergillus spp. and Fusarium by more than $90 \%$ and had better performance than the fungicides fipronil and fludioxinil + metalaxyl-M. In another study, Silva et al. (25) found lower incidence of Curvularia sp., Fusarium spp., Alternaria spp. and Bipolaris in rice seeds treated with carbendazim + thiram at the dose of $3 \mathrm{~mL} / \mathrm{kg}$ of seed, as well as higher germination percentage.

Low doses $(0.1$ to $1 \%)$ of the fungicide carboxin + thiram are not effective in controlling fungi and do not have negative effect on germination and development of seedlings of B. capitata (26). But a high dose of carboxin + thiram $(8.75 \mathrm{~mL} / \mathrm{kg})$ promoted a reduction of 


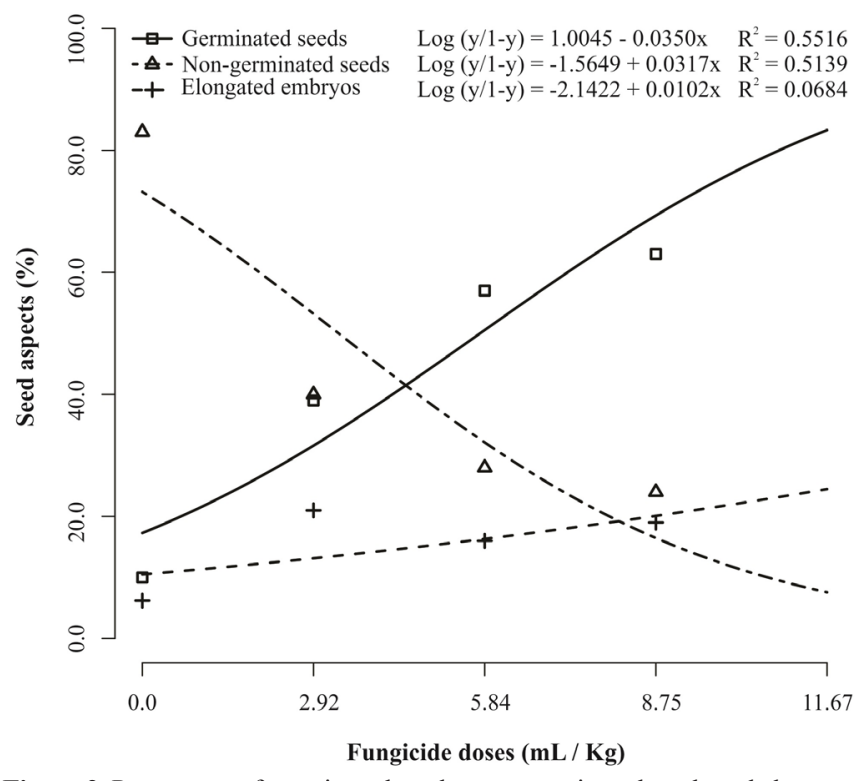

Figure 2. Percentage of germinated seeds, non-germinated seeds and elongated embryos according to the doses of the fungicide carbendazim + thiram at 40 days after treatment.

96, 97 and 98\% in the incidence of Aspergillus spp., Curvularia sp. and Penicillium spp., respectively, as well as a $52.5 \%$ increase in seed germination (Tables 1 and 2). There was a negative correlation between seed treatment with fungicide and incidence of Curvularia sp. ( $\mathrm{r}=$ -0816), Penicillium spp. $(\mathrm{r}=-0537)$, Aspergillus spp. $(\mathrm{r}=-0$ 420) and a positive correlation with seed germination $(\mathrm{r}=0.866)$ and embryo elongation $(r=0.321)$. However, despite the reduced fungal effect and increased germination rate of seeds after treatment with fungicide, there was a little increase in the germination percentage, compared with the studies of Fior et al. (7), who managed $90 \%$ germination under aseptic conditions. The temperature of $30^{\circ} \mathrm{C}$ is defined as most favorable for $B$. capitata germination (7). In this study, the average daily temperature in the experimental plots was $30.9^{\circ} \mathrm{C}$, which is consistent with the temperature required for germination. On the other hand, the B. capitata fruits used in this experiment were stored during 4 months under uncontrolled environmental conditions. Apparently, this factor, combined with fungal occurrence, may have contributed to reduce the germination potential of seeds, decreasing their physiological quality due to intensification of the deterioration phenomenon.

There were few seeds with symptoms of bacterial exudation during the operculum removal process and the experiment. This suggests that the low bacterial infestation on the seed did not allow the identification of significant interaction between the bactericide kasugamycin and the fungicide carbendazim + thiram, or its effect on control and germination.

In summary, this study demonstrated the potential of the chemical treatment of $B$. capitata seeds with the fungicide carbendazim + thiram to control Curvularia sp., Penicillium spp. and Aspergillus spp., resulting in increased germination percentage, which can be an effective measure to produce good quality seedlings.

\section{ACKNOWLEDGEMENTS}

We thank "Conselho Nacional de Desenvolvimento Científico e Tecnológico-CNPq" for providing scientific initiation scholarships to the first and second authors and research productivity scholarship to the fifth author.

\section{REFERENCES}

1. Abati, J.; Zucareli, C.; Foloni, J.S.S.; Henning, F.A.; Brzezinski, C.R.; Henning, A.A. Treatment with fungicides and insecticides on the physiological quality and health of wheat seeds. Journal of Seed Science, Londrina, v.36, n.4, p.392-398, 2014.

2. Baskin, J.M.; Baskin, C.C. A classification system for seed dormancy. Seed Science Research, Cambridge, v.14, n.1, p.1-16, 2004.

3. Bittencourt, S.R.M.; Menten, J.O.M.; Araki, C.A.S.; Moraes, M.H.D.; Rugai, A.R.; Dieguez, M.J.; Vieira, R.D. Eficiência do fungicida carboxin+ thiram no tratamento de sementes de amendoim. Revista Brasileira de Sementes, Londrina, v.29, n.2, p.214-222, 2007.

4. BRASIL. Ministério da Agricultura, Pecuária e Abastecimento. Regras para análise de sementes. Brasília, DF: Secretaria de Defesa Agropecuária/ MAPA/ACS, 2009. 398p.

5. Dias, D.S.; Lopes, P.S.N.; Ribeiro, L.M.; Oliveira, L.A.A.; Mendes, E.V.; Carvalho, V.S. Effects of seed structures, sucrose and gibberellic acid on the germination of Butia capitata (Arecaceae). Seed Science and Technology, Zurich, v.41, n.1, p.371-382, 2013.

6. Fawole, O.B.; Ahmed, O.; Balogun, O.S. Pathogenicity and cell walldegrading enzyme activities of some fungal isolates from cowpea (Vigna unguiculata $[\mathrm{L}]$ Walp). Biokemistri, Ilorin, v.18, n.1, p.45-51, 2006.

7. Fior, C.S.; Rodrigues, L.R.; Leonhardt, C.; Schwarz, S.F. Superação de dormência em sementes de Butia capitata. Ciência Rural, Santa Maria, v.41, n.7, p.1150-1153, 2011.

8. Grisi, P.U., Santos, C.M.; Fernandes, J.J. Sá Júnior, A. Qualidade das sementes de girassol tratadas com inseticidas e fungicidas. Bioscience Journal, Uberlândia, v.25, n.4, p.28-36, 2009.

9. Khairnar, D.N. Studies on seed-borne fungi, Bio deterioration of seeds and control. International Research Journal of Science and Engineering, Amravati, v.3, n.2, p.60-62, 2015.

10. Klich, M.A.; Pitt, J.I. A laboratory guide to the common Aspergillus specie $s$ and their tel eomorphs. North Ryde: CSIRO, Division of Food Processing, 2002. $116 \mathrm{p}$.

11. Kwon, H.W.; Yoon, J.H.; Kim, S.H.; Hong, S.B.; Cheon, Y.; Ko, S.J. Detection of extracellular enzymes activities in various Fusarium spp. Mycobiology, Korean, v. 35, n.3, p.162-165, 2007.

12. Machado, J.C. Tratamento de sementes no controle de doenças. Lavras, MG: UFLA/FAEPE, 2000. 138p.

13. Magalhães, H.M.; Catão, H.C.R.M.; Sales, N.L.P.; Lima, N.F.; Lopes, P.S.N. Qualidade sanitária de sementes de coquinho-azedo (Butia capitata) no Norte de Minas Gerais. Ciência Rural, Santa Maria, v.38, n.8, p.2371-2374, 2008 .

14. Magalhães, H. M.; Lopes, P.S.N.; Ribeiro, L.M.; Sant'Anna-Santos, B.F.; Oliveira, D.M.T. Structure of the zygotic embryos and seedlings of Butia capitata (Arecaceae). Trees, Berlin, v.27, n.1, p.273-283, 2013.

15. Masumi, S.; Mirzaei, S.; Kalvandi, R.; Zafari, D. Asparaginase and amylase production by thyme endophytic fungi. Journal of Crop Protection, Tehran, v.3, n.1, p.655-662, 2014.

16. Moura, R.C.; Lopes, P.S.N.; Brandão Junior, D.S.; Gomes, J.G.; Pereira, M.B. Biometria de frutos e sementes de Butia capitata (Mart.) Beccari (Arecaceae), em vegetação natural no Norte de Minas Gerais, Brasil. Biota Neotropica, Campinas, v.10, n.2, p.415-419, 2010.

17. Lorenzi, H.; Noblick, L.R.; Khan, F.; Ferreira, E. Flora brasileira: Arecaceae (Palmeiras). Nova Odessa: Instituto Plantarum, 2010. 165p.

18. Nascimento, W.M.O.; Moraes, M.H.D. Fungos associados a sementes de açaí: efeito da temperatura e do teor de água das sementes durante o armazenamento. Revista Brasileira de Sementes, Londrina, v.33, n.3, p.415-425, 2011.

19. Pereira, C.E.; Oliveira, J.A.; Rosa, M.C.M.; Oliveira, G.E.; Costa Neto, J. Tratamento fungicida de sementes de soja inoculadas com Colletotrichum truncatum. Ciência Rural, Santa Maria, v.39, n.9, p.2390-2395, 2009.

20. Pizzinatto, M.A.; Bovi, M.L.A.; Soave, J.; Spiering, S.H.; Binotti, C.S. Tratamento químico de sementes de pupunheira, (Bactris gasipaes), efeitos na sanidade, germinação e vigor. Summa Phytopathologica, Botucatu, v.26, p.42-47, 2000

21. Reis, E.M.; Danelli, A.; Casa, R.T. Fungicides, seed dresser adjuvants and storage time in the control of Drechslera teres in barley seeds. Summa Phytopathologica, Botucatu, v.38, p.187-191, 2012.

22. Ribeiro, L.M., Souza, P.P.; Rodrigues, J.R.; Oliveira, T.G.S.; Garcia, Q.S. 
Overcoming dormancy in macaw palm diaspores, a tropical species with potencial for use as bio-fuel. Seed Science and Technology, Bassersdorf, v.39, n.2, p.303-317, 2011.

23. Rocha, F.S.; Catão, H.C.R.M.; Brandão, A.A.; Gomes, L.A.A. Danos causados por diferentes potenciais de inóculo de Aspergillus ochraceus no vigor de sementes de soja. Semina: Ciências Agrárias, Londrina, v.35, n.6, p.2895-2904, 2014.

24. Santos, G.R.; Tschoeke, P.H.; Silva, L.G.; Silveira, M.C.A.C.; Reis, H.B.; Brito, D.R.; Carlos, D.S. Sanitary analysis, transmission and pathogenicity of fungi associated with forage plant seeds in tropical regions of Brazil. Journal of Seed Science, Londrina, v.36, n.1, p.54-62, 2014.

25. Silva, C.S.; Lucca Filho, O.A.; Zimmer, P.D.; Bonini Filho, R.M. Efeito do tratamento químico sobre a qualidade fisiológica e sanitária de sementes de arroz com diferentes graus de umidade. Revista Brasileira de Sementes, Londrina, v.33, n.3, p.426-434, 2011.

26. Souza, A.Í.R.C.; Neves, S.C.; Silva, P.O.; Andrade, I.G.; Ribeiro, L.M.; Lopes, P.S.N. Efeito de fungicidas no cultivo in vitro de embriões de coquinho-azedo. Unimontes Científica, Montes Claros, v.15, n.2, p.1-7, 2013.

27. Tavares, L.C.; Mendonça, A.O.; Zanatta, Z.C.N.; Brunes, A.P.; Villela, F.A. Efeito de fungicidas e inseticidas via tratamento de sementes sobre o desenvolvimento inicial da soja. Enciclopédia Biosfera, Goiânia, v.10, n.18, p.1400-1409, 2014.

28. Vries, R.P.; Visser, J. Aspergillus enzymes involved in degradation of plant cell wall polysaccharides. Microbiology and Molecular Biology Reviews, Washington, DC, v.65, n.4, p.497-522, 2001. 